\title{
PENENTUAN HARGA PRODUK PLYWOOD MENGGUNAKAN METODE ACTIVITY BASED COSTING SYSTEM
}

\author{
Nugroho Noto Susanto, Mochammad Chaeron, Sutrisno \\ Jurusan Teknik Industri, FTI Universitas Pembangunan Nasional "Veteran" Yogyakarta \\ Jl. Babarsari 2 Tambakbayan, Yogyakarta, 55281 \\ Telp. (0274) 485363 Fak : (0274) 486256
}

\begin{abstract}
ABSTRAK
PT Mapan Wijaya adalah perusahaan yang memproduksi plywood. Plywood merupakan material papan yang tersusun dari beberapa lapis kayu melalui proses perekatan dan pemampatan tekanan tinggi. Harga pasar produk plywood sangat dipengaruhi oleh perilaku konsumen, jika daya konsumtif turun maka dapat terjadi penurunan harga pasar dan sebaliknya. PT. Mapan Wijaya dalam menentukan harga produk plywood hanya mengikuti keadaan harga pasar, tanpa mempertimbangkan informasi mengenai biaya produksi. Hal tersebut menyebabkan perusahaan tidak bisa mengetahui besarnya keuntungan secara pasti.

Tujuan penelitian ini adalah menentukan harga produk plywood secara lebih akurat dengan mempertimbangkan informasi-informasi biaya di dalam proses produksi. Metode yang digunakan adalah Activity Based Costing (ABC) System dengan melakukan 7 langkah, yaitu: mengidentifikasi produk yang menjadi obyek biaya, menghitung biaya langsung produk plywood, memilih dasar pengalokasian biaya yang akan digunakan untuk mengalokasikan biaya tidak langsung ke produk plywood, mengidentifikasi biaya tidak langsung yang berkaitan dengan setiap dasar alokasi biaya, menghitung tarif per kubik dasar alokasi biaya guna mengalokasikan biaya tidak langsung ke produk, menghitung biaya tidak langsung yang dialokasikan ke produk plywood dan menghitung total biaya produk dengan menjumlahkan semua biaya.

Harga produk plywood dengan menggunakan metode Activity Based Costing (ABC) System yang mempertimbangkan informasi-informasi dalam proses produksi adalah sebesar $R p$ 3.426.550,45 per meter kubik.
\end{abstract}

Kata Kunci: harga, plywood, Activity Based Costing System

\section{PENDAHULUAN}

PT Mapan Wijaya adalah perusahaan yang bergerak dalam bidang industri plywood. Plywood merupakan produk setengah jadi, karena itu produk plywood memiliki pasar tersendiri dan tidak adanya campur tangan pemerintah untuk mengatur harga produk plywood. Hal tersebut menyebabkan kondisi harga pasar plywood tidak menentu. Harga pasar plywood sangat dipengaruhi oleh perilaku konsumen, jika daya konsumtif turun maka dapat terjadi penurunan harga pasar plywood dan begitupun sebaliknya. Dengan hal itu PT. Mapan Wijaya dituntut untuk menetapkan harga yang mampu mengikuti keadaan pasar produk plywood.

Selama ini PT. Mapan Wijaya dalam menentukan harga produk plywood masih mengikuti keadaan harga pasar, tanpa mempertimbangkan informasi tentang biaya produksi. Akibatnya perusahaan tidak dapat mengetahui biaya untuk memproduksi produk plywood secara pasti. Sementara perusahaan harus dapat memberikan harga produk plywood dengan cepat untuk menghadapi masalah ketidakstabilan harga pasar produk plywood. Maka perlu dilakukan penelitian mengenai penentuan harga produk yang mempertimbangkan informasiinformasi dalam proses produksinya

\section{Biaya}

Pengertian biaya menurut Hansen dan Mowen (2003), adalah kas atau nilai ekuivalen kas yang dikorbankan untuk mendapatkan barang atau jasa yang diharapkan memberi manfaat saat ini atau dimasa datang bagi organisasi. Menurut Horngren et al. (2005), biaya dapat diklasifikasikan menjadi 2 jenis yaitu biaya langsung dan biaya tidak langsung. Biaya langsung (direct cost) adalah suatu objek biaya terkait dengan suatu objek biaya dan 
dapat dilacak ke objek biaya tertentu dengan cara yang layak secara ekonomi (biayaefektivitas). Dengan kata lain biaya langsung terjadi dimana penyebab satu-satunya adalah karena ada sesuatu yang harus dibiayai. Biaya tidak langsung (indirect cost) adalah suatu objek biaya berkaitan dengan suatu objek biaya namun tidak dapat dilacak ke objek biaya tertentu dengan cara yang layak secara ekonomis (biaya-efektivitas). Biaya ini disebut juga sebagai biaya overhead pabrik (BOP).

Terdapat istilah kekurangan (undercosting) atau kelebihan (overcosting) biaya dalam melakukan perhitungan biaya, pengertiannya yaitu kekurangan biaya (undercosting) sebuah produk membutuhkan sumber daya dalam jumlah banyak tetapi justru memiliki biaya per unit yang rendah dan kelebihan biaya (overcosting) sebuah produk mengkonsumsi sumber daya dalam jumlah sedikit tetapi justru memiliki biaya per unit yang tinggi.

\section{Harga Pokok Produksi}

Pengertian harga pokok produksi menurut Muhadi dan Siswanto (2002) dalam Pawiyataningrum (2014) harga pokok (biaya) produksi adalah biaya yang terjadi dalam rangka untuk menghasilkan barang jadi (produk) dalam perusahaan manufaktur. Metode penentuan harga pokok produksi adalah cara menghitung unsur-unsur biaya ke dalam harga pokok produksi.

\section{Metode Activity Based Costing (ABC) System}

Menurut Hilton et al (2003) dalam Dicky dan Martusa (2011) mendefinisikan Activity Based Costing (ABC) System adalah sistem perhitungan biaya yang berusaha memperbaiki sistem perhitungan tradisional dengan menekankan pada aktivitas sebagai objek biaya dasar. Aktivitas bisa berupa kejadian, tugas atau unit pekerjaan dengan tujuan khusus, seperti contoh: perancangan produk, penyetelan mesin, pengoperasian mesin dan pendistribusian produk. Biayabiaya yang tidak bisa dibebankan langsung ke dalam produk dibebankan pada aktivitasaktivitas dan biaya-biaya pada masingmasing aktivitas tersebut dibebankan pada produk berdasarkan proporsi konsumsi produk tersebut pada masing-masing aktivitas.

\section{Hierarki Biaya (cost hierarchy) \\ Menurut Horngren et al (2005) hierarki biaya (cost hierarchy) mengelompokkan biaya berdasarkan} beberapa faktor seperti jenis pemicu biaya atau dasar alokasi biaya (cost driver), atau perbedaan tingkat kesulitan, dalam menentukan hubungan sebab akibat. Activity Based Costing (ABC) System biasanya menggunakan hierarki biaya dengan empat tingkatan untuk mengidentifikasi dasar alokasi biaya yang sedapat mungkin merupakan pemicu biaya pada kelompok biaya berdasarkan aktivitas. Menurut Horngren et al. (2005) keempat tingkatan pada hierarki biaya tersebut adalah:

a. Biaya pada tingkat unit produksi

b. Biaya pada tingkat kelompok produksi

c. Biaya pendukung yang berkaitan dengan barang dan jasa

d. Biaya pendukung fasilitas

\section{Hierarki Aktivitas}

Activity Based Costing (ABC) System membagi aktivitas berdasarkan hierarkinya. Setiap biaya sumber daya harus dibebankan ke masing-masing aktivitas yang ada didalam perusahaan. Salah satu atribut yang terpenting menurut Hilton et al (2003) dalam Dicky dan Martusa (2011) adalah mengklasifikasikan aktivitas manufakturing kepada dimensi hierarki biaya: unit, batch, product, customer and facility sustaining.

Unit level activities adalah aktivitas yang dilakukan untuk setiap unit produksi atau jasa. Jumlah dari unit level activities berjumlah proporsional dengan volume produksi dan volume penjualan. Di dalam unit level activities terdapat biaya-biaya yang melekat langsung pada unit produk atau dan dapat langsung ditelusuri pada unit produk atau jasa.

Batch level activities adalah aktivitas yang dilakukan untuk setiap batch atau penyetelan. Batch level activities ini contohnya menyetel mesin untuk produksi baru, pembelian bahan baku dan memproses order customer. Didalam batch level activities terdapat biaya-biaya yang tidak secara langsung melekat pada unit produk 
atau jasa atau tidak dapat langsung ditelusuri pada unit produk atau jasa. Product-level resources and activity diperoleh dan dilaksanakan untuk memproduksi dan menjual barang atau jasa secara spesifik. Product-level resources and activities dapat ditelusuri kepada produk atau jasa secara spesifik tetapi tidak dapat dihubungkan secara langsung dengan batch atau pada produksi unit barang atau jasa secara individual.

Customer-level resources and activity dapat diperoleh dan dilaksanakan untuk melayani pelanggan. Aktivitas pelanggan ini meliputi konsultasi dengan konsumen dan membuat pengaturan distribusi khusus untuk pelanggan tertentu.

Facility-level resources and activity dapat diperoleh dan dilakukan untuk menyediakan kapasitas secara umum untuk memproduksi barang atau jasa. Facility-level resources and activity secara langsung dihubungkan dengan skala, lingkup dan lokasi operasi produksi tetapi tidak secara langsung dihubungkan dengan konsumen, produk, batch dan produksi unit barang atau jasa secara individual.

6. Perhitungan biaya dengan Activity Based Costing (ABC) System

Menurut Horngren et al (2005)

Dalam melakukan pengolahan data dengan menggunakan Activity Based Costing (ABC) System diperlukan beberapa langkah sebagai berikut:

a. Identifikasi produk yang menjadi objek biaya. Tujuannya adalah menghitung total biaya, biaya manufaktur dan biaya distribusi per unit produk.

b. Hitung biaya langsung dari produk. Biaya langsung contohnya biaya bahan baku dan biaya tenaga kerja langsung.

c. Pilih dasar pengalokasian biaya yang akan digunakan untuk mengalokasikan biaya tidak langsung ke produk. Penentuan dasar alokasi biaya menentukan jumlah kelompok berdasarkan aktivitas pada sistem ABC, karena banyak aktivitas yang mempunyai pemicu biaya yang sama.

d. Identifikasikan biaya tidak langsung yang berkaitan dengan setiap dasar alokasi biaya. Pada tahap ini, biaya tidak langsung dialokasikan sebisa mungkin berdasarkan hubungan sebab akibat antara dasar alokasi biaya dan biaya aktivitas.

e. Hitung tarif per unit dasar alokasi biaya guna mengalokasikan biaya tak langsung ke produk. Tarif per unit dasar alokasi biaya dihitung dengan membagi total biaya pada masing-masing aktivitas dengan kuantitas dasar alokasi biaya.

f. Hitung biaya tidak langsung yang dialokasikan ke produk. Untuk menghitung total biaya tidak langsung pada setiap produk, maka total kuantitas dari dasar alokasi biaya yang digunakan setiap aktivitas oleh tiap produk dikalikan dengan tarif alokasi biaya yang telah dihitung.

g. Hitung total biaya produk dengan menjumlahkan semua biaya. Semua biaya langsung dan biaya tidak langsung dijumlahkan untuk mendapatkan total biaya produk.

\section{METODOLOGI PENELITIAN}

Penelitian dilakukan di PT. Mapan Wijaya, yang merupakan perusahaan di bidang industri plywood. PT. Mapan Wijaya menghasilkan produk-produk yang berkualitas tinggi. Produk yang dihasilkan adalah Plywood dengan grade UTY, UTY BETTER atau BB/CC. Plywood/Multipleks adalah papan material (veneer) yang disusun secara melintang serat untuk mendapatkan kestabilan dan kekuatan menahan penyusutan kayu, melalui proses perekatan dan dipres di bawah tekanan tinggi.

Langkah awal yang dilakukan adalah mengumpulkan data. Selanjutnya adalah pengolahan data untuk melakukan analisis penentuan harga produk dengan mempertimbangkan informasi dalam proses produksinya, sehingga dapat memberikan informasi biaya yang lebih akurat untuk memproduksi satu unit produk plywood. Pengolahan data dilakukan menggunakan metode Activity Based Costing (ABC) System dengan beberapa langkah sebagai berikut:

a. Mengidentifikasi produk yang menjadi objek biaya.

b. Menghitung biaya langsung produk plywood. Menentukan biaya-biaya 
langsung, adalah sebagai berikut: biaya bahan baku, biaya bahan pembantu dan biaya tenaga kerja langsung. Biaya langsung dibebankan kepada produk plywood dengan cara sebagai berikut:

Biaya bahan baku per $m^{3}(B B B)=$ Total biaya bahan baku

$\overline{\text { Total produksi plywood }}$

Biaya bahan pembantu per $m^{3}(B B P)=$ Total biaya bahan pembantu

Total produksi plywood

Biaya tenaga kerja langsung per $m^{3}(B T K L)=$ Jumlah gaji per bulan $\times$ waktu produksi $1 \mathrm{~m}^{3}$ plywood Jumlah jam operasi per bulan

Biaya langsung $(B L)=B B B+$ $B B P+B T K L$

c. Memilih dasar pengalokasian biaya yang akan digunakan untuk mengalokasikan biaya tidak langsung ke produk plywood. Penulis menentukan aktivitas overhead pabrik untuk mengalokasikan biaya tidak langsung ke produk plywood, yang terdiri dari: operasi manufaktur, perawatan mesin, tenaga kerja tidak langsung, perawatan pabrik, penyusutan pabrik, administrasi umum dan pemasaran. Langkah awal dalam pembebanan biaya tidak langsung adalah menentukan activity cost driver untuk masing-masing aktivitas overhead pabrik. Sebelum menentukan activity cost driver, terlebih dahulu membagi aktivitas berdasarkan cost hierarchy untuk masing-masing aktivitas.

d. Mengidentifikasi biaya tidak langsung yang berkaitan dengan setiap dasar alokasi biaya. Pada tahap ini, biaya tidak langsung dialokasikan sebisa mungkin berdasarkan hubungan sebab akibat antara dasar alokasi biaya dan biaya aktivitas.

e. Menghitung tarif per kubik dasar alokasi biaya guna mengalokasikan biaya tidak langsung ke produk. Tarif dasar alokasi biaya dihitung menggunakan data total biaya yang dikeluarkan pada masingmasing aktivitas overhead pabrik. Kemudian total biaya dibagi dengan kuantitas dasar alokasi biaya, untuk menghitung tarif dasar alokasi biaya pada masing-masing aktivitas overhead pabrik.

Tarif alokasi biaya tidak langsung = Total biaya per aktivitas overhead pabrik

Kuantitas dasar alokasi biaya

f. Menghitung biaya tidak langsung yang dialokasikan ke produk plywood. Untuk menghitung total biaya tidak langsung produk plywood, maka total kuantitas dasar alokasi biaya yang digunakan setiap aktivitas oleh produk plywood dikalikan dengan tarif dasar alokasi biaya yang telah dihitung. Selanjutnya rumus perhitungan biaya tidak langsung yang di bebankan ke produk plywood adalah:

Biaya tidak langsung $(B T L)=$ Kuantitas produk plywood $\times$ Tarif alokasi biaya tidak langsung Total produksi plywood

g. Menghitung total biaya produk dengan menjumlahkan semua biaya. Semua biaya langsung dan biaya tidak langsung dijumlahkan untuk mendapatkan total biaya produk. Dari hasil perhitungan didapatkan harga pokok produksi (HPP) produk plywood per meter kubik.

Harga pokok produksi $(H P P)=$
$B L+B T L$

h. Perusahaan menargetkan keuntungan yang harus diperoleh adalah sebesar $10 \%$.

Harga jual produk $=H P P+$ $10 \% H P P$

\section{PEMBAHASAN}

1. Pengumpulan data

Langkah awal yang dilakukan melakukan pengolahan data diawali dengan mengumpulkan data yang meliputi: data laporan laba rugi bulan Januari 2017, data penjualan produk plywood di bulan Januari 
ISSN 1693-2102

OPSI - Jurnal Optimasi Sistem Industri

2017, data jumlah jam kerja di bulan Januari 2017, dan data flow proses produk plywood.

\section{Pengolahan data}

Pengolahan data dilakukan menggunakan metode Activity Based Costing (ABC) System dengan beberapa langkah sebagai berikut:

a. Mengidentifikasi produk yang menjadi objek biaya. Dalam hal ini yang menjadi objek biaya adalah produk plywood. Sehingga tujuannya adalah menghitung total biaya langsung dan biaya tidak langsung yang seharusnya dikeluarkan oleh perusahaan untuk memproduksi per meter kubik produk plywood.

b. Menghitung biaya langsung produk plywood terdiri dari: biaya bahan baku sebesar Rp 2.083.757,953, biaya bahan pembantu sebesar Rp 336.964,125 dan biaya tenaga kerja langsung sebesar Rp 305.168,535. Sehingga total biaya langsung produk plywood adalah $\mathrm{Rp}$ 2.725.890,613.

c. Memilih dasar pengalokasian biaya yang akan digunakan untuk mengalokasikan biaya tidak langsung ke produk plywood. Langkah awal dalam pembebanan biaya tidak langsung ke produk ini adalah menentukan activity cost driver-nya yang akan digunakan sebagai dasar alokasi biaya aktivitas. Sebelum menentukan activity cost driver, aktivitas terlebih dahulu dibagi berdasarkan cost hierarchy untuk masing-masing aktivitas.

Tabel 1. Penentuan Cost Hierarchy

\begin{tabular}{|l|l|l|}
\hline No. & Nama Aktivitas & Cost Hierarchy \\
\hline 1 & Biaya Operasi Manufaktur & Batch level \\
\hline 2 & Biaya Perawatan Mesin & Facility Sustaining \\
\hline 3 & Biaya Tenaga Kerja Tidak Langsung & Facility Sustaining \\
\hline 4 & Biaya Perawatan Pabrik & Facility Sustaining \\
\hline 5 & Biaya Penyusutan Pabrik & Facility Sustaining \\
\hline 6 & Administrasi dan Umum & Facility Sustaining \\
\hline 7 & Pemasaran & Batch level \\
\hline
\end{tabular}

Tabel 2. Penentuan Activity Cost Driver

\begin{tabular}{|l|l|l|}
\hline No. & Nama Aktivitas & Activity Cost Driver \\
\hline 1 & Biaya Operasi Manufaktur & Jumlah Jam Pemakaian Mesin/Bulan \\
\hline 2 & Biaya Perawatan Mesin & Jumlah Jam Pemakaian Mesin/Bulan \\
\hline 3 & Biaya Tenaga Kerja Tidak Langsung & Jumlah Jam Kerja TKTL/Bulan \\
\hline 4 & Biaya Perawatan Pabrik & Jumlah Jam Kerja TKL/Bulan \\
\hline 5 & Biaya Penyusutan Pabrik & Jumlah Jam Kerja TKL/Bulan \\
\hline 6 & Administrasi dan Umum & Jumlah Penjualan/Bulan \\
\hline 7 & Pemasaran & Jumlah Pengiriman/Bulan \\
\hline
\end{tabular}

d. Mengidentifikasi biaya tidak langsung yang berkaitan dengan setiap dasar alokasi biaya. Pengalokasian biaya tidak langsung ke produk plywood dapat dilakukan berdasarkan penetapan Activity Cost Driver untuk masingmasing aktivitas.

e. Menghitung tarif per kubik dasar alokasi biaya guna mengalokasikan biaya tidak langsung, sebagaimana terlihat pada Tabel 3.

f. Menghitung biaya tidak langsung yang dialokasikan ke produk plywood, sebagaimana terlihat pada Tabel 4.

Tabel 3. Perhitungan tarif alokasi biaya tidak langsung pada masing-masing aktivitas

\begin{tabular}{|c|c|c|c|}
\hline Aktivitas & Total Biaya & Kuantitas Dasar Alokasi Biaya & Tarif Alokasi Biaya Tidak Langsung \\
\hline Biaya Operasi Manufaktur & Rp 241.060.225 & 525 jam pemakaian mesin & Rp 459.162,3/jam pemakaian mesin \\
\hline Biaya Perawatan Mesin & 40.520 .135 & 525 jam pemakaian mesin & Rp 77.181,2/jam pemakaian mesin \\
\hline Biaya Tenaga Kerja Tidak Langsung & 108.800 .200 & 200 jam kerja TKTL & Rp 544.001/jam kerja TKTL \\
\hline Biaya Perawatan Pabrik & 905.000 & 525 jam kerja TKL & Rp 1.723,8/jam kerja TKL \\
\hline Biaya Penyusutan Pabrik & 150.000 .000 & 525 jam kerja TKL & Rp 285.714,3/jam kerja TKL \\
\hline Administrasi dan Umum & 74.688 .465 & $1.652,583 \mathrm{~m}^{3}$ penjualan/bulan & Rp $45.195 / \mathrm{m}^{3}$ penjualan \\
\hline Pemasaran & 81.726 .500 & $3 \mathrm{x}$ pengiriman $/$ bulan & Rp 27.242.166,7/pengiriman \\
\hline
\end{tabular}

Tabel 4. Biaya tidak langsung yang dialokasikan ke produk plywood 


\begin{tabular}{|c|c|c|c|}
\hline Aktivitas & $\begin{array}{l}\text { Kuantitas dari Aktivitas yang } \\
\text { Digunakan untuk Produk Plywood }\end{array}$ & Tarif Alokasi Biaya Tidak Langsung & Biaya per Kubik \\
\hline Biaya Operasi Manufaktur & 508,3 jam mesin & Rp 459.162,3/jam pemakaian mesin & Rp 145.848,2915 \\
\hline Biaya Perawatan Mesin & 508,3 jam mesin & Rp $77.181,2 /$ jam pemakaian mesin & $24.515,8328$ \\
\hline Biaya Tenaga Kerja Tidak Langsung & 193,6 jam kerja TKTL & Rp 544.001/jam kerja TKTL & $65.814,2694$ \\
\hline Biaya Perawatan Pabrik & 508,3 Jam kerja TKL & Rp 1.723,8/jam kerja TKL & 547,5477 \\
\hline Biaya Penyusutan Pabrik & 508,3 Jam kerja TKL & Rp 285.714,3/jam kerja TKL & $90.754,2769$ \\
\hline Administrasi dan Umum & $1.600,2395 \mathrm{~m}^{3}$ Penjualan/Bulan & Rp $45.195,9 / \mathrm{m}^{3}$ penjualan & $45.195,9856$ \\
\hline Pemasaran & $96,8 \%$ & Rp 27.242.166,7/pengiriman & $16.479,0441$ \\
\hline Total & & & Rp 389.155,248 \\
\hline
\end{tabular}

g. Menghitung total biaya produk dengan menjumlahkan semua biaya, sebagaimana terlihat pada Tabel 5 .

Tabel 5. Total biaya produksi produk plywood

\begin{tabular}{ll}
\hline Keterangan & Total Biaya \\
\hline Biaya Langsung & Rp 2.725.890,613 \\
Biaya Tidak Langsung & Rp 389.155,248 \\
\hline Total Biaya Produksi & Rp 3.115.045,861 \\
\hline
\end{tabular}

h. Sehingga harga produk plywood jika diinginkan keuntungan sebesar 10\% bisa ditetapkan sebagai berikut:

Harga Produk Plywood $=\mathrm{Rp}$

$3.115 .045,861+(\operatorname{Rp} 3.115 .045,861 \mathrm{x}$ $10 \%)=\operatorname{Rp} 3.426 .550,447$

\section{Analisis Hasil}

Perhitungan biaya produksi yang dilakukan oleh PT. Mapan Wijaya mengalami kelebihan biaya (overcosting). Hal ini dapat menyebabkan PT. Mapan Wijaya tidak mampu bersaing dengan perusahaan sejenis yang dapat memberikan harga jual lebih rendah dalam menghadapi keadaan harga pasar yang tidak menentu. Permasalahan ini menjadi kesalahan perhitungan biaya yang dilakukan oleh PT. Mapan Wijaya saat ini, melakukan perhitungan biaya produksi secara cepat tanpa mempertimbangkan informasiinformasi dalam proses produksi. Perbedaan yang terjadi antara perhitungan biaya oleh PT. Mapan Wijaya dan perhitungan Activity Based Costing (ABC) System disebabkan karena perbedaan pembebanan biaya overhead pabrik pada produk. Pada perhitungan PT. Mapan Wijaya biaya overhead pabrik hanya dibebankan pada satu pemicu biaya saja. Sedangkan pada perhitungan Activity Based Costing (ABC) System, biaya overhead pabrik pada produk dibebankan pada banyak pemicu biaya sesuai dengan aktivitas-aktivitas yang dilakukan dalam proses produksi. Sehingga dalam metode Activity Based Costing (ABC) System mampu mengalokasikan biaya aktivitas ke produk dengan lebih akurat.

Manfaat lain dari Activity Based Costing (ABC) System sebagai penyedia informasi untuk membuat keputusan yang lebih tepat. Penentuan harga produk plywood di PT. Mapan Wijaya dilakukan per-periode, dimana satu periode berlangsung selama 3 (tiga) bulan. Jika tingkat konsumsi pasar produk plywood stabil selama periode berlangsung, maka harga yang sudah ditentukan saat ini dapat digunakan untuk 3 bulan kedepan. Jika tingkat konsumsi pasar produk plywood menurun dan menyebabkan turunnya harga produk plywood, maka manajemen dituntut untuk menentukan harga produk plywood yang dapat mengikuti keadaan pasar. Hal ini dilakukan untuk mempertahankan perusahaan di persaingan pasar produk plywood. Menghadapi masalah ketidakstabilan harga, perusahaan harus dapat menentukan harga secara cepat dan lebih akurat. Disarankan agar perusahaan menentukan harga produk plywood dengan menerapkan metode Activity Based Costing $(A B C)$ System sehingga menghasilkan informasi harga pokok produksi yang relevan sebagai dasar pengambilan keputusan manajemen. 


\section{KESIMPULAN}

PT. Mapan Wijaya dalam menentukan harga produk plywood belum memberikan perhitungan biaya produksinya secara akurat, hal tersebut dapat dilihat dari produk plywood mengalami kelebihan biaya (overcosting). Berdasarkan hasil penelitian dan pembahasan masalah yang telah dilakukan dalam penentuan harga produk plywood dengan menggunakan metode Activity Based Costing (ABC) System yang mempertimbangkan informasi-informasi dalam proses produksi, dapat ditarik kesimpulan bahwa harga produk plywood adalah sebesar Rp 3.426.550,447 per meter kubik.

\section{DAFTAR PUSTAKA}

Dicky, Y., dan Martusa. R., 2011. Penerapan Activity Based Costing (ABC) System dalam Penghitungan Profitabilitas Produk, Jurnal Akuntansi, Vol 3, No.1, Hal. 69-89

Farahmita, A., Amanugraha, Hendrawan, dan Taufik, 2008, Product, http://www.investorwords.com/3874/pro duct.html, diakses pada 31 Maret 2017 pukul 13.39

Hansen, M., dan M. Mowen, 2003, Cost Management: Accounting and Control, Edisi ke-4, Salemba Empat, Jakarta

Hilton, R. W., M. W. Michael, S. H. Frank, 2003, Cost Management: Strategies for Business Decisions, The McGraw Hill Companies Inc., New York.

Horngren, Foster dan Datar, dialihbahasakan oleh Desi Adhariani, 2005, Akuntansi Biaya: Penekanan Manajerial, Edisi ke11, PT Indeks Kelompok Gramedia, Jakarta.

Mulyadi, 2002, Akuntansi Biaya, Edisi ke-5, cetakan ke-9, Aditya Media, Yogyakarta

Nugroho, 2016, Analisis Penentuan Biaya Pelayanan Penggergajian Kayu dengan Metode Activity Based Costing, Tugas Akhir, UPN "Veteran" Yogyakarta.

Pawiyataningrum, A.N., Sudjana, N. dan Zahroh, Z.A., 2014, Penerapan Activity Based Costing (ABC) System untuk Menentukan Harga Pokok Produksi, Jurnal Administrasi Bisnis, Vol 10, No.1. Hal. 1-9. 